\title{
METODE PEMBELAJARAN PROBLEM BESED LEARNING DALAM UPAYA MENINGKATKAN PENCAPAIAN PEMBELAJARAN MATA KULIAH KEPERAWATAN MEDIKAL BEDAH III PADA MAHASISWA SEMESTER IV JURUSAN KEPERAWATAN POLITEKNIK KESEHATAN SURAKARTA
}

\author{
Dwi Susi Haryati, Yeni Tutu Rohimah \\ Kementerian Kesehatan Politeknik Kesehatan Surakarta Jurusan Keperawatan
}

\begin{abstract}
Methods of Learning, Problem Based Learning, Learning Achievement. This study aims to assess the Problem Based Learning in improving achievement of learning outcomes in the Course of Medical Surgical Nursing III on IV semester student of polytechnic nursing Surakarta. The method used in this research was experimental research with quasi-experimental design (posttest control group designs). The mean value of the pre-test knowledge of the discussion group $54 \pm 9.65$. The mean value of post test discussion group $74.16 \pm 4.46, p=0.000$ a significant improvement. The mean value of pre test $P B L$ group $54.1 \pm 8.25$, the mean value of post test knowledge PBL group $74.00 \pm 4.4, p=0.000$ a significant improvement. The mean value of Psychomotor (skills) in a discussion group discussion group $92.5 \pm 6.08$, the mean value of $92.92 \pm P B L$ group skills 6,24.Rerata value attitudes discussion group $87.0 \pm$ 3.43 , the mean value of the attitude of PBL group $86.7 \pm 3.42$. Problem Based Learning method can improve the achievements of Course Study abroad in Medical Surgical Nursing III on IV semester student of polytechnic nursing Surakarta.
\end{abstract}

Keywords: Method of Learning, Problem Based Learning, Learning Achievement

\begin{abstract}
Abstrak: Metode Pembelajaran, Problem Based Learning, Pencapaian Pembelajaran. Penelitian ini bertujuan untuk mengkaji Problem Based Learning dalam upaya peningkatan capaian hasil belajar pada Mata Kuliah Keperawatan Medikal Bedah III pada mahasiswa semester IV Jurusan keperawatan Poltekkes Surakarta. Metode penelitian yang digunakan dalam penelitian ini adalah penelitian eksperimen dengan rancangan quasi eksperimen (post test control group designs). Rerata nilai pre test pengetahuan kelompok diskusi $54 \pm 9,65$. Rerata nilai post test kelompok diskusi 74,16 $\pm 4,46$, peningkatannya bermakna $\mathrm{p}=0,000$. Rerata nilai pre test kelompok PBL 54,1 \pm 8,25 , rerata nilai pengetahuan post test kelompok PBL 74,00 $\pm 4,4$, peningkatannya bermakna $\mathrm{p}=0,000$. Rerata nilai Psikomotor (keterampilan) pada kelompok diskusi diskusi kelompok 92,5 \pm 6,08, rerata nilai keterampilan kelompok PBL 92,92 \pm 6,24. Rerata nilai sikap kelompok diskusi 87,0 \pm 3,43, Rerata nilai sikap kelompok PBL $86,7 \pm 3,42$. Metode Problem Based Learning dapat meningkatkan capaian hasil balajar pada Mata Kuliah Keperawatan Medikal Bedah III pada mahasiswa semester IV Jurusan Keperawatan Poltekkes Surakarta.
\end{abstract}

Kata Kunci: Metode Pembelajaran, Problem Based Learning, Pencapaian Pembelajaran 


\section{PENDAHULUAN}

Metode mengajar merupakan cara yang digunakan pendidik dalam membelajarkan peserta didik agar terjadi interaksi dan proses belajar yang efektif dalam pembelajaran. Setiap metode mengajar mempunyai karakteristik yang berbeda-beda dalam membentuk pengalaman belajar peserta didik, tetapi satu dengan yang lainnya saling menunjang.

Pembelajaran klasikal yang masih didominisasi oleh kegiatan dosen di dalam klas masih banyak di lakukan, sedangkanpembelajaran yang bersifat andragogik yang paling sering digunakan adalah diskusi kelompok di mana peran dosen pada metode ini adalah membagi materi untuk kelompok kemudian bertindak sebagai fasilitator sebelum hasil kerja kelompok dipresentasikan di dalam klas.

Dibeberapa perguruan tinggi terutama pendidikan kedokteran saat ini telah mengembangkan metode pembelajaran Problem Based Learning (PBL) dengan metode seven jump. Metode PBL merupakan cara yang efektif untuk menyelenggarakan pendidikan yang memerlukan teori dan keterampilan secara koheren dan terintegrasi, serta memberi berbagai keuntungan dan nilai lebih bagi mahasiswa bila dibandingkan metoda pengajaran tradisional. PBL didasarkan atas prinsip adult learning theory, termasuk memotivasi dan mendorong mahasiswa untuk menyusun dan menetapkan tujuan belajar, serta memberi kesempatan kepada mahasiswa untuk berperan dalam pengambilan keputusan yang berdampak pada proses pembelajaran mereka.

Dari studi Pendahuluan pada mahasiswa semester III Klas C Jurusan
Keperawatan Politeknik Kesehatan Surakarta yang telah menerapkan metode PBL pada mata Kuliah Keperawatan Medikal Bedah I (KMBI) pada 8 sub pokok bahasan dan lebih dan 10 sub pokok bahasan menggunakan metode ceramah, didapakan nilai Ujian baik Ujian tengah Semester maupun Ujian Akhir Semester sebagian besar peserta didik masih belum memenuhi target nilai yang disyaraktan yaitu nilai 68 pada ujian utama.

\section{METODE PENELITIAN}

Jenis penelitian yang digunakan dalam penelitian ini adalah penelitian eksperimen dengan rancangan quasi eksperimen (post test control group designs). Pelaksanaan penelitian ini dilaksanakan bulan Februari - Juli2015 sedangkan tempat penelitian adalah Jurusan Keperawatan Politeknik Kesehatan Surakarta. Populasi pada penelitian ini adalah semua mahasiswa semester IV keperawatan. Sampel pada penelitian ini adalah smester IV klas C sebanyak 48 orang. Pelaksanaan penelitian ini dilaksanakan bulan Februari - Juli 2015 sedangkan tempat penelitian adalah Jurusan Keperawatan Politeknik Kesehatan Surakarta.

\section{HASIL PENELITIAN}

\section{Tabel 1}

Rerata Nilai Pre dan Post Test

Pengetahuan kelompok Diskusi dan

PBL

\begin{tabular}{cccc}
\hline Metode & Pre Tes & Post Tes & $p$ \\
& & & \\
\hline Nilai & & & \\
\hline Diskusi & $54 \pm 9,65$ & $74,16 \pm 4,6$ & 0,00 \\
\hline PBL & $54,1 \pm$ & $74,00 \pm 4,4$ & 0,00 \\
& 8,25 & & \\
\hline$p$ & 0,975 & 0,899 & \\
\hline
\end{tabular}


Dari tabel di atas dapat dilhat rata rata nilai pre test pengetahuan kelompok diskusi 54 dengan standar deviasi 9,65, rata-rata nilai pre test kelompok PBL 54,1 dengan standar deviasi 8,25, hasil uji t-test menunjukan $\mathrm{p}=0,975, \mathrm{p}>0,05$ tidak ada perbedaan nilai pre test antara kelompok diskusi dengan kelompok PBL sehingga dapat diambil kesimpulan bahwa pengetahuan awal responden sama. Ratarata nilai post test kelompok diskusi74,16 dengan standar deviasi 4,46 , rata-rata nilai post test kelompok PBL 74,00 dengan standar deviasi 4,4 hasil uji $\mathrm{t}$ - test pre test dan post test pada kelompok diskusi $\mathrm{p}$ $0,000, \mathrm{p}<0,05$ ada perbedaan bermakna antara hasil pre test dan post pada kelompok diskusi. Hasil uji $\mathrm{t}$ - test antara pre test dan post test pada kelompok PBL menunjukan $\mathrm{p}=0,000, \mathrm{p}<0,05$, ada perbedaan bermakna hasil pre test dan post test pada kelompok PBL. Hasil uji ttest antara post test kelompok diskusi dengan kelompok PBL menunjukan $\mathrm{p}=$ 0,899, $\mathrm{p}>0,05$ ada perbedaan bermakna post test antara kelompok diskusi dengan kelompok PBL.

\section{Tabel 2}

Rerata Nilai Keterampilan kelompok Diskusi dan PBL

\begin{tabular}{cccc}
\hline Metode & Diskusi & PBL & $\mathrm{p}$ \\
& & & \\
\hline Nilai & $92,5 \pm 6,08$ & $92,92 \pm$ & 0,816 \\
& & 6,24 & \\
\hline
\end{tabular}

Dari tabel di atas dapat dilhat rata rata nilai keterampilan kelompok diskusi 92,5 dengan standar deviasi 6,08, rata-rata nilai keterampilan kelompok PBL 92,92 dengan standar deviasi 6,24, hasil uji t-test menunjukan $\mathrm{p}=0,816, \mathrm{p}>0,05$ tidak ada perbedaan nilai keterampilan antara kelompok diskusi dengan kelompok PBL.
Tabel 3.

Rerata Nilai Sikap kelompok Diskusi dan PBL

\begin{tabular}{cccc} 
Metode & Diskusi & PBL & $\mathrm{p}$ \\
\hline Nilai & $87,0 \pm 3,43$ & $86,7 \pm 3,42$ & 0,77 \\
\hline
\end{tabular}

Dari tabel di atas dapat dilhat rata rata nilai sikap kelompok diskusi 87,0 dengan standar deviasi 3,43, rata-rata nilai sikap kelompok PBL 86,7 dengan standar deviasi 3,42, hasil uji t-test menunjukan $\mathrm{p}$ $=0,77, \mathrm{p}>0,05$ tidak ada perbedaan nilai sikap antara kelompok diskusi dengan kelompok PBL.

\section{PEMBAHASAN}

Dari hasil analisis $\mathrm{t}$ - test di dapatkan bahwa perbedaan rerata nilai pengetahuan antara pre test dan post tes pada kelompok diskusi berbeda bermakna $\mathrm{p}=0,000, \mathrm{p}<0,05$, perbedaan rerata nilai pengetahuan pre tes dan post tes pada kelompok PBL berbeda bermakana $\mathrm{p}=$ $0,000, \quad \mathrm{p}<0,05$. Rerata nilai pengetahuankelompok diskusi dengan kelompok PBL tidak berbeda bermakna $p$ $=0,899, \mathrm{p}>0,05$, dari hasil analisis tersebut dapat disimpulkan bahwa baik metode diskusi kelompok maupun Metode PBL sama efektifnya dalam meningkatkan capaian hasil belajar.

Knowles (1993) dalam Nursalam (2003) mengemukakan bahwa dalam proses pembelajaran orang dewasa terdapat tujuh aspek utama, yaitu suasana, perencanaan, diagnosa kebutuhan, penentuan tujuan belajar, rumusan rencana belajar, kegiatan belajar dan evaluasinya, ketujuh aspek tersebut di dalam proses pembelajaran diskusi maupun PBL sama-sama terpenuhi. Suasana diskusi kelompok maupun PBL dapat dijlankan dengan santai, saling mempercayai, saling menghargai, 
informal, dalam situasi yang penuh kehangatan, salingbekerjasama, dan saling mendukung antar anggota kelompok. Pada diagnosa kebutuhan pembelajaran baik pada diskusi maupun pada PBL fasilitator bersama-dengan peserta didik menentukan kebuhan pencapaian apa yang diinginkan pada pembelajaran saat itu. Pada pencapaian tujuan pembelajaran baik pada diskusi dilakukan maupun PBL dilakuan dengan bekerjasama dan perundingan sehingga tujuan pembelajaran terarah pada hasil akhir dari pembelajaran. Desain rencana belajar baik diskusi maupun PBL terdapat perjanjian belajar (learning contracts), Projek belajar (learning projects), serta urutan belajar atas dasar kesiapan (sequenced by readiness) karena baik pada metode diskusi maupun metode PBL mahasiswa sudah memiliki bekal pengetahuan dasar pada materi yang akan didiskusikan. Ealuasi belajar Oleh peserta didik baik pada metode diskusi maupun metode PBL berdasarkan evidensi yang dipelajari oleh rekan-rekan, fasiltator, ahli (by learner-collected evidence validated by peers, facilitators, experts), Referensinya berdasarkan criteria (criterion-referenced).

Proses belajar pada kelompok PBL diawali dengan menelaah kasus sedangkan pada kelompok diskusi kelompok diawali dengan menelaah pokok bahasan, selanjutnya baik pada kelompok diskusi kelompok maupun kelompok PBL peserta didik belajar bekerjasama memberikan argumentasi dan ide-ide dalam kelompokkelompok kecil atau kelompok besar secara kolaboratif dengan struktur kelompok yang hiterogen dan memiliki kemampuan yang berbeda-beda, sehingga peserta didik dapat memanfaatkan teman sejawat (peserta didik lain) sebagai rekan dalam memecahkan masalah atau mendiskusikan materi-materi yang telah ditentukan kepada kelompok-kelompok tersebut, dan mereka dapat saling membantu dan tukar menukar pendapat dan ide yang pada akhirnya dapat merangsang peserta didik lebih bergairah dalam belajar, dan dalam sistem ini guru sebagai fasilitator dan pengarah efektifitas pembelajaran.

Rerata nilai keterampilan antara kelompok diskusi dengan kelompok PBL tidak berbeda bermakna $\mathrm{p}=0,816, \mathrm{p}>$ 0,05 ,sehingga dapat disimpulkan baik metode diskusi kelompok maupun metode PBL sama efektifnya dalam meningkatkan capaian hasil belajar.

Penilaian ranah psikomotorik yaitu ranah yang berkaitan dengan aspek-aspek keterampilan yang melibatkan fungsi sistem syaraf dan otot (neuronmuscular system) dan fungsi psikis. Ranah ini terdiri dari kesiapan (set), peniruan (imitation), membiasakan (habitual), menyesuaikan (adaptation), dan menciptakan (origination).Ketika peserta didik telah memahami dan menginternalisasikan nilai-nilai mata pelajaran dalam dirinya, maka tahap selanjutnya ialah bagaimana peserta didik mampu mengaplikasikan pemahamannya dalam kehidupan sehari-hari melalui perbuatan atau tindakan. Pada penelitian ini mahsiswa baik untuk kelompok diskusi kelompok maupun untuk kelompok PBL untuk belajar keterampilan menggunakan SOP yang telah disusun oleh tim pembelajaran $\mathrm{KMB}$, sehingga dari responden mampu mengaplikasikan pemahaman melalui tindakan yang harus mereka lakukan.

Haryati Mimin (2009) mengatakan dalam ranah psikomotor atau keterampilan peserta didik harus memiliki kemampuan Persepsi (Perception) Penggunaan alat 
indera untuk menjadi pegangan dalam membantu gerakan. Kesiapan (Set) Kesiapan fisik, mental, dan emosional untuk melakukan gerakan. Guided Response (Respon Terpimpin) Tahap awal dalam mempelajari keterampilan yang kompleks, termasuk di dalamnya imitasi dan gerakan coba-coba. Mekanisme (Mechanism) Membiasakan gerakangerakan yang telah dipelajari sehingga tampil dengan meyakinkan dan cakap. Respon Tampak yang Kompleks (Complex Overt Response) Gerakan motoris yang terampil yang di dalamnya terdiri dari pola-pola gerakan yang kompleks.

Rerata nilai sikap antara kelompok diskusi dengan kelompok PBL tidak berbeda bermakna $\mathrm{p}-0,77, \mathrm{p}>0,05$. sehingga dapat disimpulkan baik metode diskusi kelompok maupun metode PBL sama efektifnya dalam meningkatkan capaian hasil belajar.

\section{KESIMPULAN DAN SARAN}

Rerata nilai pre test pengetahuan kelompok diskusi $54 \pm 9,65$. Rerata nilai post test kelompok diskusi 74,16 $\pm 4,46$, peningkatannya bermakna $\mathrm{p}=0,000$. Rerata nilai pre test kelompok PBL 54,1 \pm 8,25 , rerata nilai pengetahuan post test kelompok PBL 74,00 \pm 4,4, peningkatannya bermakna $\mathrm{p}=0,000$

$$
\text { Rerata nilai Psikomotor }
$$

(keterampilan) pada kelompok diskusi diskusi kelompok 92,5 $\pm 6,08$, rerata nilai keterampilan kelompok PBL 92,92 $\pm 6,24$. Rerata nilai sikap kelompok diskusi 87,0 $\pm 3,43$, Rerata nilai sikap kelompok PBL $86,7 \pm 3,42$. Metode Problem Based Learning dapat meningkatkan capaian hasil balajar pada Mata Kuliah Keperawatan Medikal Bedah III pada mahasiswa semester IV Jurusan keperawatan Poltekkes Surakarta.

Saran untuk Penelitian ini, Selain Metode Diskusi Kelompok, Metode PBL dapat digunakan sebagai metode pembelajaran pada Mata Kuliah Keperawatan. Serta untuk mendapatkan hasil yang lebih baik lagi pada peneliti lainnya disarankan untuk menggunakan beberapa sub pokok bahasan dan penilaian psikomotor dan sikap dilaksanakan di lahan praktek.

\section{DAFTAR RUJUKAN}

Barrows HS, Tamblyn RM. Problembased learning: an approach to medical education. Medical Education. Vol.I New York; Springer, 1980.

Mimin Haryati. Model Dan Teknik Penilaian Pada Tingkat Satuan Pendidikan, (Jakarta: Gaung Persada Press, 2009), hlm. 22.

Mohammad Muchlis Solichin. Psikologi Belajar: Aplikasi Teori-Teori Belajar Dalam Proses Pembelajaran (Yogyakarta: Suka Press, 2012), hlm. 86-87

Nursalam, Pendidikan Dalam

Keperawatan. Salemba Medika, Bandung, 2003. 